\title{
Ideas and perspectives: Southwestern tropical Atlantic coral growth response to atmospheric circulation changes induced by ozone depletion in Antarctica
}

\author{
Heitor Evangelista $^{1}$, Ilana Wainer ${ }^{2}$, Abdelfettah Sifeddine $^{3,4}$, Thierry Corrège ${ }^{5}$, Renato C. Cordeiro $^{3}$, \\ Saulo Lamounier ${ }^{1}$, Daniely Godiva ${ }^{1,3}$, Chuan-Chou Shen ${ }^{6}$, Florence Le Cornec ${ }^{4}$, Bruno Turcq ${ }^{4}$, Claire E. Lazareth ${ }^{4}$, \\ and Ching-Yi $\mathrm{Hu}^{6}$ \\ ${ }^{1}$ LARAMG/IBRAG/Uerj. Pav. HLC, Subsolo, Rua São Francisco Xavier 524, Maracanã - Rio de Janeiro, \\ 20550-013, Brazil \\ ${ }^{2}$ Universidade de São Paulo - USP/IO/Departamento de Oceanografia Física, Praça do Oceanográfico 191, \\ 05508-120 São Paulo, SP, Brazil \\ ${ }^{3}$ Departamento de Geoquímica, Instituto de Química - UFF, Outeiro de São João Batista s/n, Centro - Niterói, \\ 24020-007, Brazil \\ ${ }^{4}$ IRD-Sorbonne Universités (UPMC, Univ Paris 06)-CNRS-MNHN, LOCEAN Laboratory. IRD France-Nord, 32, avenue \\ Henri Varagnat, 93143 Bondy, France \\ ${ }^{5}$ Université de Bordeaux, UMR CNRS 5805 EPOC, Allée Geoffroy St Hilaire, 33615 Pessac Cedex, France \\ ${ }^{6}$ High-Precision Mass Spectrometry and Environment Change Laboratory (HISPEC), Department of Geosciences, \\ National Taiwan University, Roosevelt Rd., Taipei 10617, Taiwan ROC
}

Correspondence to: Heitor Evangelista (evangelista.uerj@gmail.com)

Received: 17 May 2015 - Published in Biogeosciences Discuss.: 17 August 2015

Revised: 12 March 2016 - Accepted: 26 March 2016 - Published: 25 April 2016

\begin{abstract}
Recent Southern Hemisphere (SH) atmospheric circulation, predominantly driven by stratospheric ozone depletion over Antarctica, has caused changes in climate across the extratropics. Here, we present evidence that the Brazilian coast (southwestern Atlantic) may have been impacted from both wind and sea-surface temperature changes derived from this process. Skeleton analysis of massive coral species living in shallow waters off Brazil are very sensitive to air-sea interactions, and seem to record this impact. Growth rates of Brazilian corals show a trend reversal that fits the ozone depletion evolution, confirming that ozone impacts are far reaching and potentially affect coastal ecosystems in tropical environments.
\end{abstract}

\section{Introduction}

Sensitivity of coral species to change in sea surface temperature (SST) has become a focus of attention in the context of modern climate change (Coles and Jokiel, 1978; Howe and Marshall, 2002; Cantin et al., 2010). Response to thermal stress ranges from growth rate alteration to bleaching and eventually death. SST has long been recognized as an important environmental driver for coral growth pattern and calcification (Lough and Barnes, 1997). In a scenario of a warming planet, it is expected that until 2050, approximately $95 \%$ of global reefs will be under pressure from thermal stress and that only $15 \%$ will remain in areas of adequate aragonite saturation that are considered ideal for coral development (Burke, 2011). Brazilian coral species have high level of endemism and are predominantly found in shallow waters, with the scleractinian coral Siderastrea stellata (Verril, 1868) being one of the main reef builders. It is a colonial, massive, and symbiotic coral (Lins-de-Barros and Pires, 2007) with a spatial distribution that encloses all Brazilian 
reefs and coral communities from nearly 0 to $23^{\circ} \mathrm{S}$ (Castro and Pires, 2001). For Siderastrea stellata, that often grows in shallow water in reef tidal pools (where temperatures normally range between 25 and $31^{\circ} \mathrm{C}$ ), optimum calcification has been observed at temperatures between 28 and $30^{\circ} \mathrm{C}$. For this particular species, the aragonite saturation seems to play a less relevant role than SST for calcification, especially when SST reaches $\sim 26^{\circ} \mathrm{C}$ (da Silva et al., 2009).

Several factors can induce change in SST that will ultimately impact coral communities. One of them is the change in wind circulation patterns. Several authors have reported a close relationship between wind stress and SST (Lindzen and Nigam, 1987; Hashizume et al., 2001; Chelton et al., 2007) through modulation of surface heat flux and upper ocean mixing. In general, warmer SST can be associated with deeper boundary layers and higher wind stress (Cayan, 1992; O'Neill et al., 2010). The Southern Hemisphere mid-to-high latitude circulation has undergone marked changes in wind dynamics over the past few decades. One of the most pronounced changes is the poleward displacement of the Southern Hemisphere westerly jet stream, which has been accompanied by a poleward shift and intensification of oceanic circulation (Thompson et al., 2000; Hartmann et al., 2000). These changes have been attributed in part to external factors such as increased air temperature due to greenhouse gases (GHG), but also to the Southern Annular Mode (SAM) variability enhanced by the Antarctic ozone depletion. The polar stratospheric ozone depletion is also believed to affect the entire Southern Hemisphere, resulting in a broadening of the Hadley cell and a poleward extension of the subtropical dry zone (Polvani et al., 2011). Trends in the Southern Hemisphere tropospheric circulation indicate that the strengthening of the westerly winds is linked to ozone loss (Thompson et al., 2011). Earlier studies (Sexton, 2001; Thompson and Solomon, 2002) postulated that the Antarctic ozone depletion was the primary cause for tropospheric circulation changes in the Southern Hemisphere that occurred in the late 1970s. Another impact of polar ozone depletion on subtropical regions was examined using the Canadian Middle Atmosphere Model (CMAM) and the National Center for Atmospheric Research (NCAR) Community Atmospheric Model (CAM3). Kang et al. (2011) showed that the ozone depletion area evolution has caused a poleward shift of the extratropical circulation, resulting in a substantial increase in subtropical precipitation in austral summer. According to Thompson et al. (2011), the influence of the ozone hole on the Southern Annular Mode has led to a range of significant summertime surface climate changes not only over Antarctica and the Southern Ocean but also over New Zealand, Patagonia, and southern regions of Australia. All in all, ozone depletion appears to have large and far-reaching impacts and to potentially be an important player in the Southern Hemisphere climate system.

One question arising is whether changes in surface winds and SST, triggered in the South Polar region, could affect the tropical South Atlantic coastal ecosystems. Considering that a warming in surface waters has been detected at the southwestern Atlantic since the 1970s and such elevation may have implications for coral metabolism and health, potentially compromising the sustainability of coral reefs, we compared time series of coral growth rate and climateoceanography modeled data to investigate impacts in costal environments, especially over the highly sensitive coral communities living in Abrolhos National Park of Brazil $\left(17^{\circ} 25^{\prime}\right.$ to $18^{\circ} 09^{\prime} \mathrm{S} ; 038^{\circ} 33^{\prime}$ to $039^{\circ} 05^{\prime} \mathrm{W}$ ), the most important coral reef site in the southwestern Atlantic.

\section{Materials and methods}

\subsection{Coral sampling}

Massive coral skeleton cores were retrieved within the scope of the Brazil-France projects RECORD (REconstructing the Climate from cORal Drilling), LMI PALEOTRACES, and the IRD-CNPq (CLIMPAST). Corals were drilled using a custom-made pneumatic corer with a $\sim 5 \mathrm{~cm}$ diameter barrel. Samples were collected in the National Park of Abrolhos, State of Bahia, Brazil. A Siderastrea stellata, labeled CS1, was sampled at Chapeirão do Sueste $\left(17^{\circ} 57^{\prime} \mathrm{S}\right.$; $038^{\circ} 38^{\prime} \mathrm{W}$ ) on 5 March 2007, water depth was $8.5 \mathrm{~m}$ and core length was $53 \mathrm{~cm}$. The sample labeled UFBA was retrieved from a colony of Favia leptophylla, at Abrolhos $\left(17^{\circ} 52^{\prime} \mathrm{S} ; 039^{\circ} 38^{\prime} \mathrm{W}\right)$ in the winter of 1977 at approximately $5 \mathrm{~m}$ water depth. The core is $28.5 \mathrm{~cm}$ long and is hosted at the Department of Geology of the Universidade Federal da Bahia. The chronology of this coral core is described in Evangelista et al. (2007). A Favia leptophylla coral labeled P1 was sampled in the vicinity of CS1, at Chapeirão do Pierre, on 4 March 2007; core length is $51 \mathrm{~cm}$. In the laboratory, CS1 and P1 cores were washed with Milli-Q water by sonication and then cut in half with a circular saw. One half was sectioned to produce a $1 \mathrm{~cm}$ thick slab that was washed again before drying at $40^{\circ} \mathrm{C}$.

\subsection{Coral skeleton chronology}

Sections of coral cores were X-rayed to generate a chronology based on yearly density band counting (Knutson et al., 1972). X-ray images were digitized and their original contrast was slightly improved in order to enhance the recognition of high and low density growth bands. Band counting took the year (and the season) of sampling as reference for chronology. In order to validate the chronology based on Xray radiography, we dated the CS1 core with the $\mathrm{U} / \mathrm{Th}$ technique, as proposed by Shen et al. (2008). For coral skeletons, the $\mathrm{U} / \mathrm{Th}$ dating method is a robust absolute chronological tool due to the high precision mass spectrometric technology and to the commonly high uranium levels (in the order of $\mathrm{ppm}$ ) in coral skeletons. Four subsamples of $\sim 0.1 \mathrm{~g}$ were taken from the core with approximately equal spacing from 

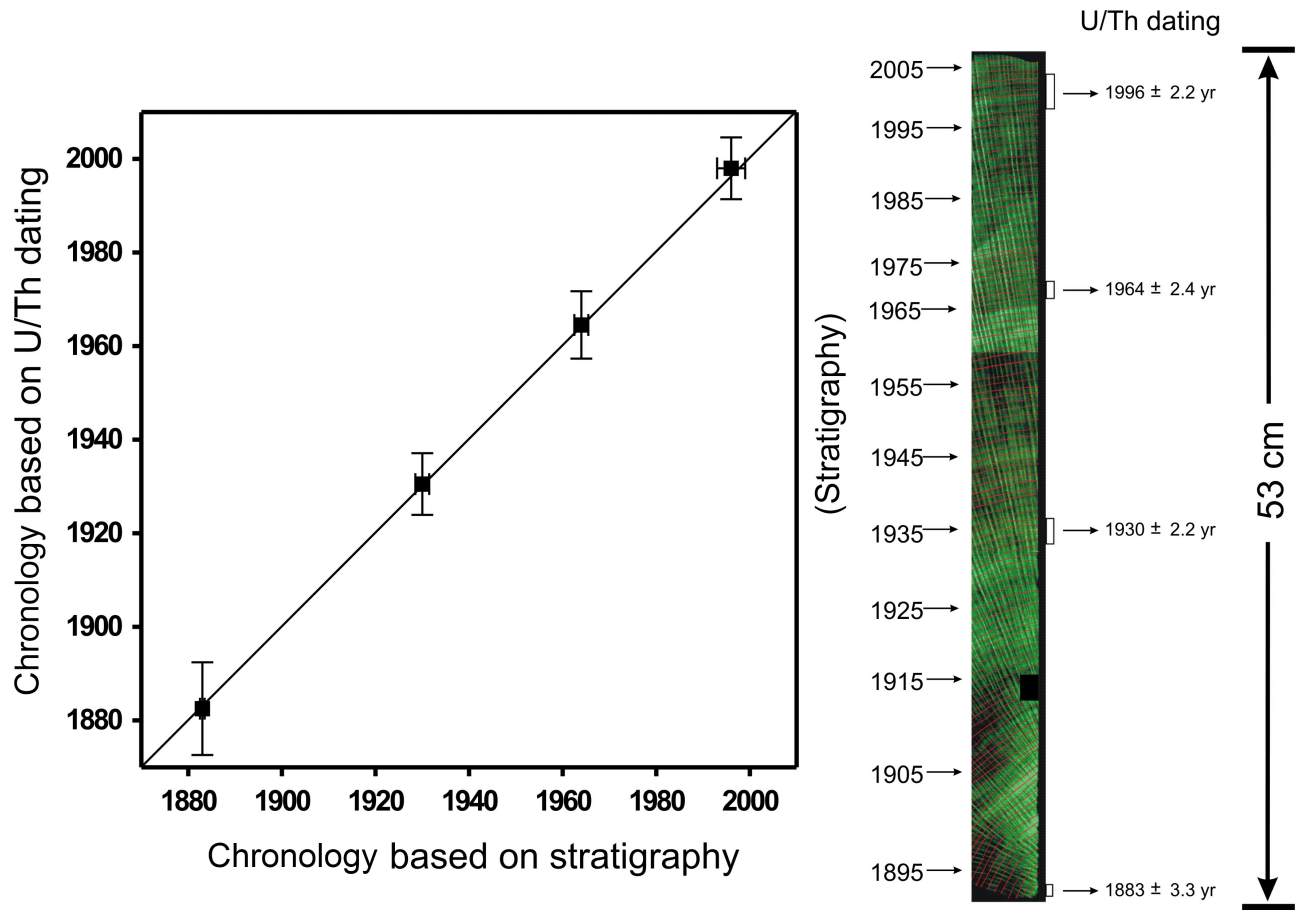

Figure 1. Comparison of chronologies obtained from X-ray radiography, named stratigraphy, and U / Th dating for a coral core of Siderastrea stellate (CS1) from Abrolhos National Park, Brazil. Error bars refer to $3 \mathrm{SD}$.

the top to the base. Age corrections were calculated using an estimated radionuclide ${ }^{230} \mathrm{Th} /{ }^{232} \mathrm{Th}$ ratio of $4 \pm 2 \mathrm{ppm}$. All radiometric analyses were carried out using a SF-ICP-MS at the High-precision Mass Spectrometry and Environmental Change Laboratory (HISPEC), Department of Geosciences, National Taiwan University (NTU) (Shen et al., 2008, 2010). Figure 1 shows the comparison of both methods.

\subsection{Instrumental data and model outputs}

Coral growth data were compared to the extent of the ozone depleted area, the wind stress, the zonal wind, the SST, and the PDO (Pacific Decadal Oscillation). The extent of the ozone depleted area over Antarctica (in million $\mathrm{km}^{2}$ ) is defined as the maximum daily area in October of each year between 1979 and 2008. Data were obtained from NASA Ozone Watch at the link ozonewatch.gsfc.nasa.gov. Ozone depletion over Antarctica was discovered in the mid-1980s (Farman et al., 1985) and was attributed to the positive trend in atmospheric halogenated hydrocarbons released by human activities (Albritton and Kuijpers, 1999; Solomon, 1999). Gradual ozone depletion recovery occurred just from the beginning of the XXI century (almost 10 years after the implementation of the Montreal Protocol in 1989 that controls emissions of ozone depleting substances). Annual mean wind stress data used here are from ERA-40 (Uppala et al., 2005) and zonal wind from NCEP-NCAR reanalysis. The NCEP/NCAR Reanalysis Project is a joint project be- tween the National Centers for Environmental Prediction and the National Center for Atmospheric Research (NCAR). It uses a state-of-the-art analysis and forecast system to perform data assimilation using data from 1948 to the present. Its latest products have time coverage of four times daily while data from 1948 to 1957 are presented in the regular (non-Gaussian) gridded data format. SST and sea level were provided by NCEP-NCAR reanalysis and the Simple Ocean Data Assimilation (SODA) (Carton and Giese, 2008) product. These parameters spanned the full existing database since 1948. PDO data are available at http://www. jisao.washington.edu. PDO is a robust, recurring pattern of ocean-atmosphere climate variability centered over the midlatitude Pacific basin, which influences a significant part of the globe, especially South America. It is a long-lived (at decadal scale) El Niño-like pattern of the Pacific climate. This parameter was considered here, since previous works have detected El Niño-like signals on growth rate of tropical Atlantic corals at Abrolhos (Evangelista et al., 2007).

\section{Results and discussions}

The three coral cores collected in Abrolhos exhibit a decline in annual growth rate towards the present (Fig. 2a, b, c). Corals used in this study were found in a healthy condition, with no sign of bleaching at the time of sampling. To blend data from the three coral cores, we used a simple Gaussian $z$-score transformation (Fig. 2d). Growth anomaly 
from individual coral cores exhibits a transition from positive to negative approximately after the mid-1960s and the 1970 s, a trend highlighted by the $z$-score compilation. Figure $2 \mathrm{~d}$ indicates that the decline in coral growth follows the SST anomaly, Fig. 2e, inversely, for the Abrolhos site. A temporal difference exists at the time when patterns change from positive to negative phases and vice versa; nevertheless it is within the uncertainties of the modeled SST and $z$ score of growth rate. Also, slopes of linear trends of SST and coral growth also differ, being steeper for SST. Other works have suggested that mean annual SSTs throughout the tropics and subtropics have increased between 0.4 and $1{ }^{\circ} \mathrm{C}$ in the past 4 decades (Kleypas et al., 2008). For Abrolhos, the mean annual SST changed from $\sim 24.8$ to $\sim 25.8^{\circ} \mathrm{C}$ between 1948 and 2006 (NCEP-NCAR reanalysis). Evidence of sharp decline in coral growth rate since the late 1970s was also reported in comparable latitudes away from South America, like that reported for genus Porites from 44 reefs in Australia (Lough et al., 2002). In a subsequent work, these authors have expanded their database to include five other reef sites (Lough, 2008). Their average time serie depicts a sharp drop in the calcification rate $\left(\mathrm{g} \mathrm{cm}^{-2} \mathrm{yr}^{-1}\right)$ starting in the late 1970s. The transition of both SST and coral growth were concomitant with zonal wind changes around Antarctica as depicted in Fig. 3a.

The 1970s were a decade when major climatic processes, largely involving the ocean, shifted phases. For example, there was a negative-to-positive phase transition of the PDO, which is associated with more frequent El Niño events (Miller et al., 1994). The atmospheric dynamics around the Antarctic continent also experienced important changes. The westerly winds increased by the end of the 1970s (Polvani et al., 2011). This intensification was coeval with the positive trend of the Antarctic Oscillation (evidenced by the AAO Index) that is the dominant pattern of nonseasonal tropospheric circulation variations south of $20^{\circ} \mathrm{S}$ and is an observationbased Southern Hemisphere Annular Mode index used to derive the zonal wind means from 40 to $65^{\circ} \mathrm{S}$ (Marshall, 2003). The positive phase of AAO is generally associated with stronger cyclones at high southern latitudes (Pezza and Ambrizzi, 2003). The intensification of the westerlies in conjunction with the positive trend of the AAO has been documented in observations, reanalysis, and climate models simulations from the mid-1960s to present (Thompson and Solomon, 2002; Gillett and Thompson, 2003; Baldwin et al., 2007). New climatic observations have provided consistent information on the influence of the Antarctic Ozone depletion in the intensification of the westerlies (Albritton and Kuijpers, 1999; Solomon, 1999). Atmospheric temperature shifts concomitant with ozone depletion have been measured at several coastal Antarctic stations from meteorological balloon profiles (Randel and Wu, 1999). One consequence of this lowering in temperature is an increase of the cold-core low-pressure area over Antarctica, the Antarctic circumpolar vortex (ACV). The intensification of the ACV may contribute

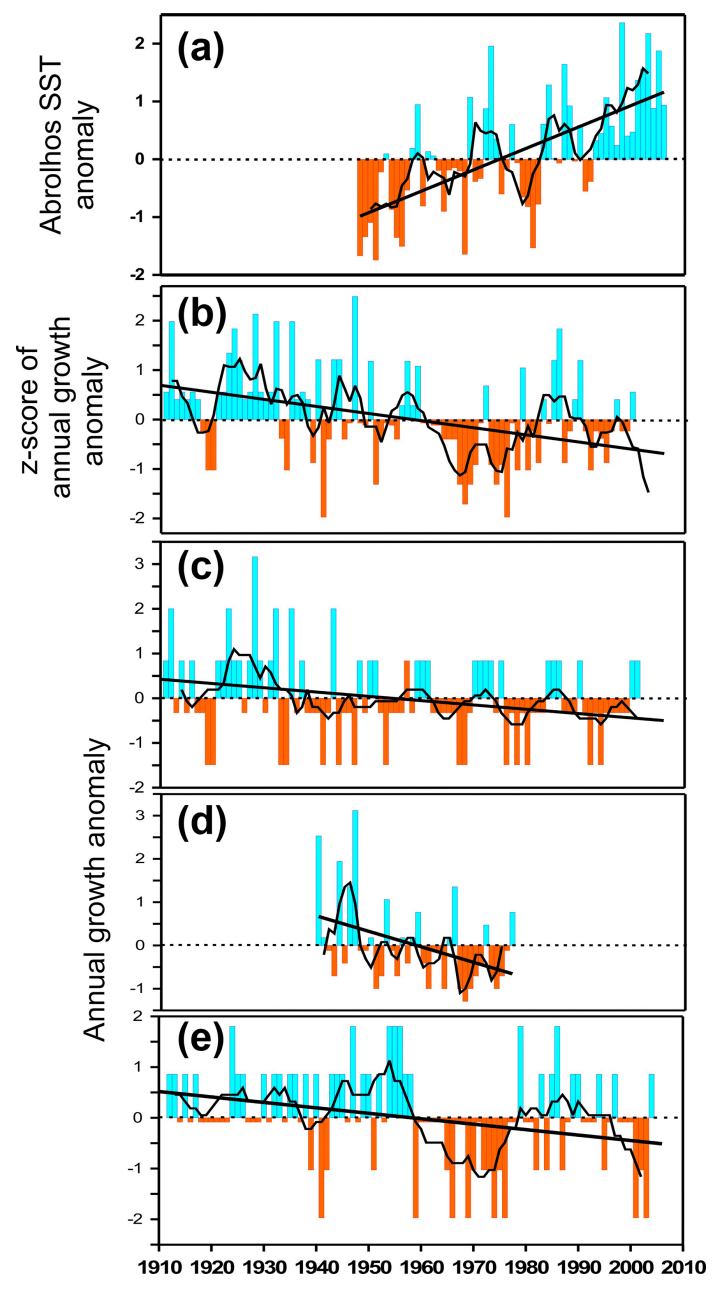

Figure 2. (a) SST anomaly for Abrolhos National Park, Brazil based on NCEP-NCAR reanalysis; (b) $z$ score for sample P1 (c), sample Abrolhos/UFBA (d) and sample CS1 (e).

to strengthening the polar-to-subtropical pressure and the air temperature gradient between central Antarctica and the surroundings affecting the westerlies. Known impacts are the poleward shift of the midlatitude jet stream and of the Hadley cell that ultimately will affect tropical SST. Figure 3 shows our calculations (based on NCEP-NCAR) of main parameters related to ozone-induced climatology and oceanography.

Southern tropospheric wind changes associated with ozone depletion have been largely discussed in the literature (Gillett and Thompson, 2003; Shindell and Schmidt, 2004; Baldwin et al., 2007; Son et al., 2008, 2009; Purich and Son, 2012). What is new here is the way winds and tropical Atlantic SSTs are impacted by ozone depletion. Based on the NCEP-NCAR reanalysis, the tropical Brazilian coast presumably experienced changes of zonal wind direction (from east to west) since 1979, as depicted in Fig. 3e. Taking into account the correlations observed between ozone depletion area (Fig. 3d) and wind stress (represented here by the length of the arrows at Fig. 3c), it points to an impact of the winds 

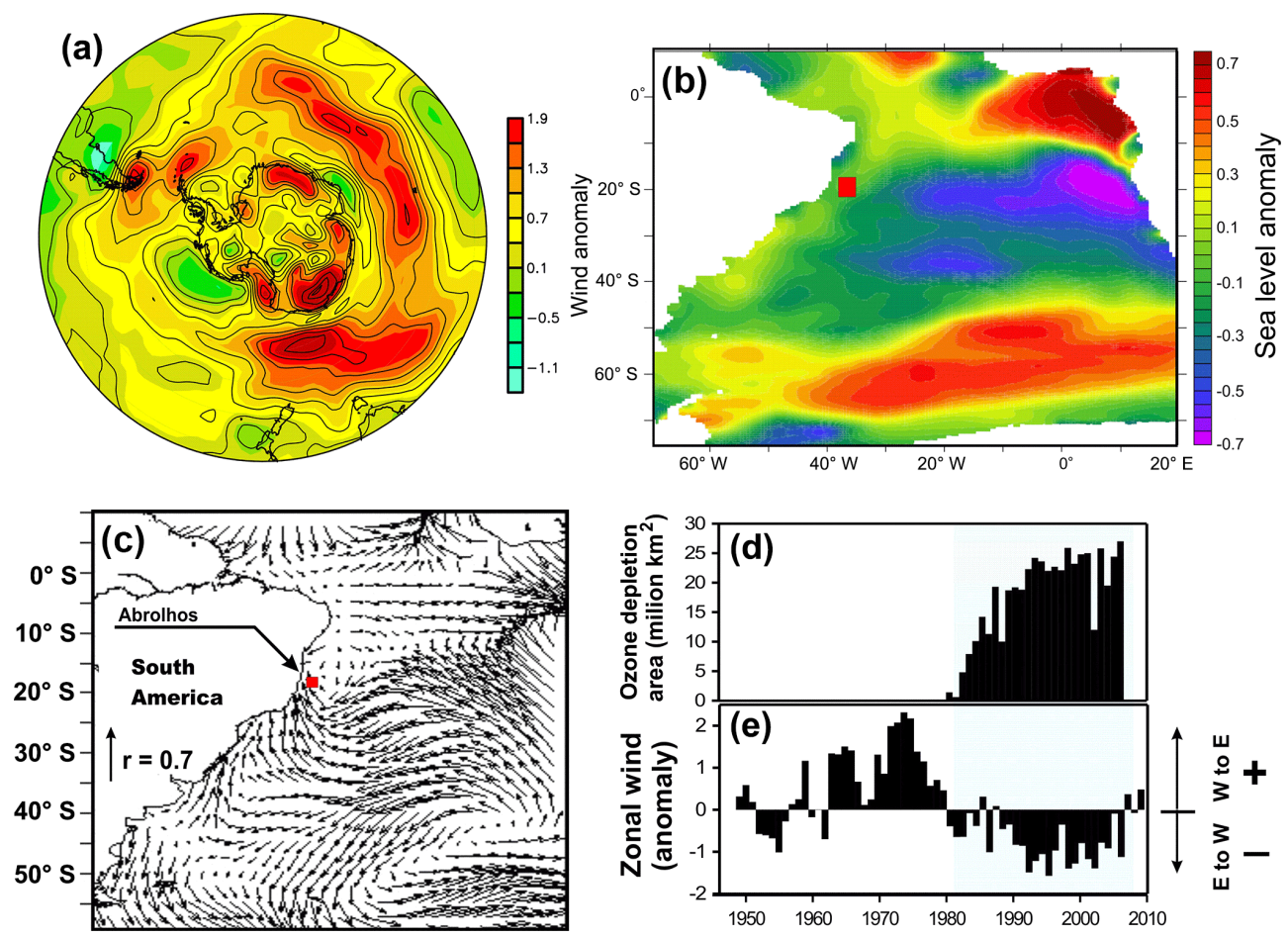

Figure 3. Calculations based on NCEP-NCAR reanalysis for: (a) the zonal winds changes around Antarctica before and after 1979, previously published in 2013 (Cataldo et al., 2013); (b) sea-level pressure difference (also before and after 1979, but with emphasis to the South Atlantic); (c) correlation of wind stress and the ozone depletion area (arrow lengths correspond to $r$ Pearson values); (d) ozone depletion area; and (e) the zonal wind anomalies calculated to the Abrolhos site.

over the latitudinal band that encloses the tropical South Atlantic sector, from Africa to the Brazilian coast, reaching the Abrolhos site. A potential impact of that is the piling up of warm waters against the Brazilian continental shelf that would result in increasing SST. The UK Meteorological Office Hadley Centre SST climatology (the best spatial and temporal resolved database which dates back to 1870 , Rayner et al., 2003) shows a clear moderate stepwise positive change of SST since 1980 on the Brazilian continental shelf (Belking, 2009). An average SST change of $\sim 1{ }^{\circ} \mathrm{C}$ was found for the period 1981-2006 with respect to 1957-1980. Long tide-gauge time series (calibrated with satellite altimetry) at Cananéia $\left(25^{\circ} \mathrm{S}\right)$ and Ilha Fiscal Stations $\left(22^{\circ} \mathrm{S}\right)$, both on the Brazilian tropical coast, exhibit sea level increase of $\sim 100 \mathrm{~mm}$ between 1976 and 2005 with respect to 19541975 and of $\sim 160 \mathrm{~mm}$ between 1971 and 2004 with respect to 1963-1970, respectively (Dalazoana et al., 2005). Figure $3 \mathrm{~b}$, based on NCEP, also depicts a positive anomaly at Abrolhos before and after 1979.

These instrumental data combined with the high positive correlation found between ozone depletion area and SST in the southwestern Atlantic sector, as shown in Fig. 4, indicate that an active mechanism links Antarctica and the tropics.

In addition, the interdecadal PDO is a significant climate variability mode when considering the 1970s climate shift being its magnitude unprecedented high since mid-20th cen-

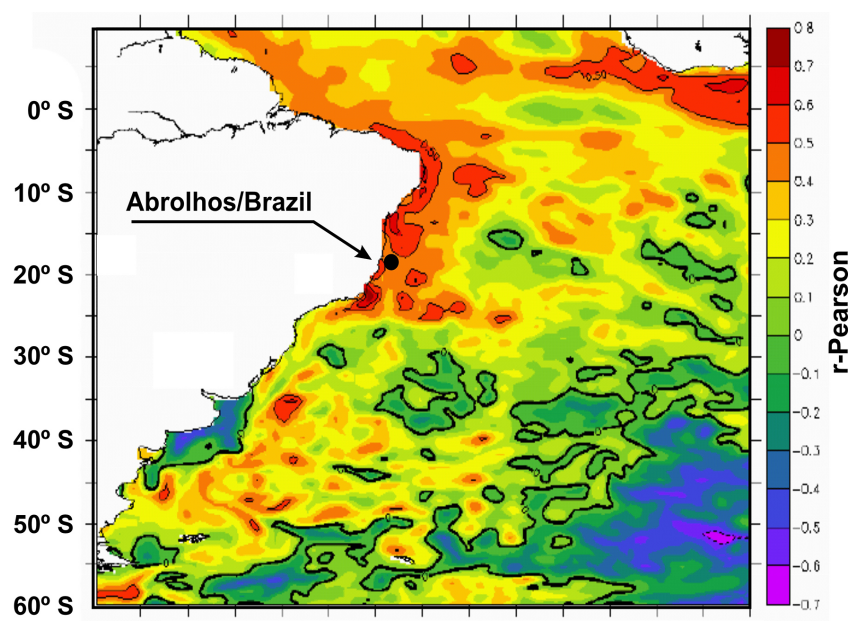

Figure 4. Correlation map between ozone depletion area in Antarctica and southwestern Atlantic SST.

tury. Several studies postulate a great contribution of the PDO to this climate shift, particularly in the Northern Hemisphere (e.g., Mantua et al., 1997). Nevertheless, according to Agosta and Compagnucci (2008), in the regional context of southern South America and the adjacent South Atlantic, changes in the basic atmospheric circulation of the late 1970s climate transition cannot be solely attributed to the PDO or 

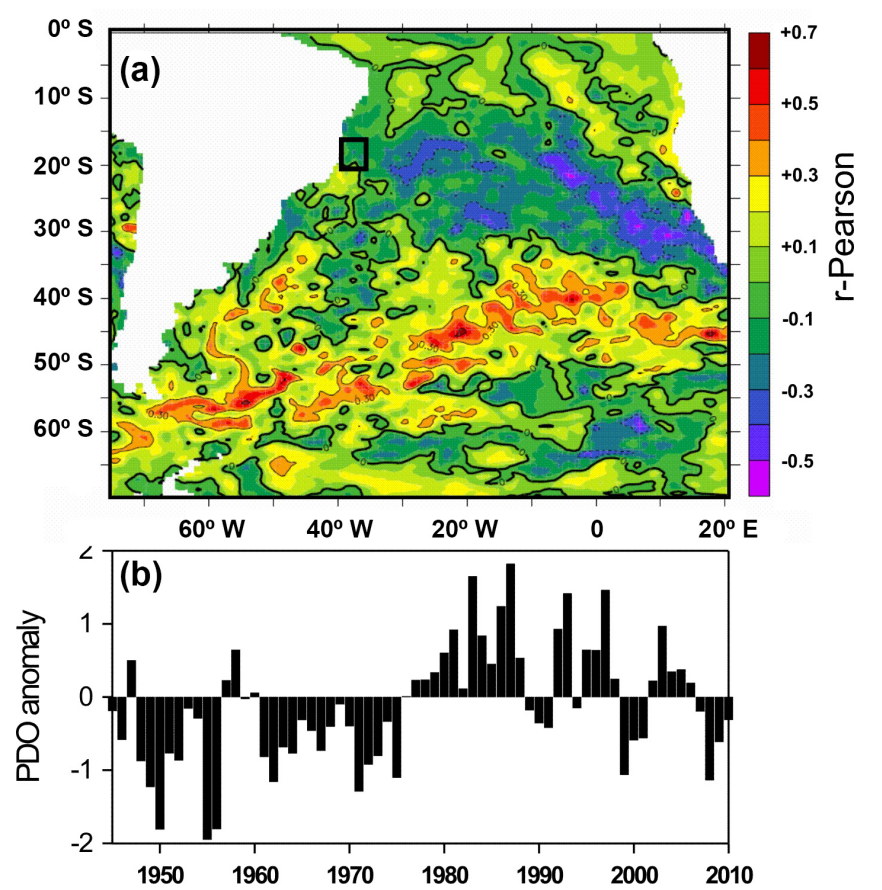

Figure 5. (a) Correlation map (SST $\times$ PDO) and; (b) PDO (Pacific Decadal Oscillation) anomaly time series, Abrolhos region.

associated El Niño-like variability. In Fig. 5 we show the correlation map between SST and PDO. The result indeed shows an impact of the PDO in the South Atlantic with significant correlation coefficients mostly occurring at a latitude band from $\sim 35$ to $65^{\circ} \mathrm{S}$.

The fact here is that significant correlation coefficients found in Fig. 5 (ozone depletion area and SST) are observed where coral communities live in the Brazilian coastal line, while the higher correlations with PDO is confined to subtropics and central Atlantic. Since $r$ Pearson values between SST and ozone at the Brazilian coral site varied from +0.6 to +0.7 , the explained variance of SST $(\sim 40 \%)$ due to the climate-induced effects (changes in atmospheric circulation) of the ozone depletion is much higher than the PDO influence at that site.

Both processes (depletion of stratospheric ozone in Antarctica and GHGs) account for reduced surface pressure over the high latitudes accompanying increase of surface pressure at midlatitudes. This is associated with the meridional temperature gradient and the position of midlatitude upper-level jet stream that modulates the tropospheric circulation (winds) and ultimately impact the SST spatial distribution. The near-surface ocean temperature is forced by winds, radiation, and freshwater fluxes. The ocean then impacts the atmosphere via latent, sensible, and radiative heat losses that are dependent on SST and fundamentally on the wind stress. Since SST is closely related to the mixing layer variability, SST variations are intimately connected with the heat budget of the mixed layer (McPhaden and Hayes, 1991;
Chen et al., 1994; Wang and McPhaden, 2000; Foltz et al., 2003). Furthermore, atmospheric circulation anomalies have been shown to precede the development of basin-wide SST patterns for the tropical Atlantic (Nobre and Shukla, 1996).

\section{Conclusions}

Records of coral growth anomaly for the Abrolhos site, Brazil, evidenced changes (from positive to negative growth rate anomaly) concomitant with SST increases at the coral living site which, in turn, were concomitant with the evolution of the area of ozone depletion. This potential teleconnected process, as described above, is of concern to tropical coastal environments in the South Atlantic, since it would constitute a factor of SST increase on a scenario of expected global warming due to GHG. Ozone levels in the stratosphere are expected to recover by the end of the century (Perlwitz et al., 2008), and that should theoretically weaken westerly winds (Arblaster and Meehl, 2006; Turner et al., 2009) and contribute to a trend reversal in zonal wind and consequently SST anomalies.

\section{Data availability}

After publication, data obtained from this work (coral growth time series) will be available at PAGES/NOAA website to be freely accessed.

Author contributions. All co-authors provided significant contribution to the discussions and the final version of the text; Heitor Evangelista, Abdelfettah Sifeddine and Bruno Turcq were the leaders of the RECORD project that generated the coral database; Ilana Wainer provided the modeling in the manuscript; Thierry Corrège, Daniely Godiva and Renato Campello Cordeiro made the coral drillings at the Brazilian coast. Thierry Corrège, Chuan-Chou Shen and Claire E. Lazareth made the final revision of the text and significatively improved it; Florence Le Cornec and Saulo Lamounier also contributed to the text and chronology of the coral cores; Chuan-Chou Shen and Ching-Yi Hu made the radioisotope analysis for dating.

Acknowledgements. We thank IBAMA for coral sampling licenses (nos. 283/2006 and 040/2007CGREP); Fundação de Amparo à Pesquisa do Estado de São Paulo-FAPESP; Coordenação de Aperfeiçoamento de Pessoal de Nível Superior-CAPES, Conselho Nacional de Pesquisa-CNPq (Grant no. 300223/93-5) and CNPq-MCTI/INCT-Criosfera (Grant no. 573720/2008). The Brazil-France scientific programs LMI PALEOTRACES, PRIMO $(\mathrm{CNPq})$ and the IRD-CNPq (CLIMPAST). NCEP Reanalysis data provided by the NOAA/OAR/ESRL PSD, Boulder, Colorado, USA. $\mathrm{U} / \mathrm{Th}$ dating was supported by grants from Taiwan ROC MOST (103-2119-M-002-022 and 104-2119-M-002-003 to C.-C.S.) and the National Taiwan University (105R7625 to C.-C.S.). 
Authors declare no existing competing financial interests in this work.

Edited by: W. Kiessling

\section{References}

Agosta, E. A and Compagnucci, R. H.: The 1976/77 Austral summer climate transition effects on the atmospheric circulation and climate in southern South America, J. Climate, 21, 4365-4383, 2008.

Albritton, D. and Kuijpers, L.: Synthesis of the Reports of the Scientific, Environmental Effects, and Technology and Economic Assessment Panels of the Montreal Protocol: a Decade of Assessments For Decision Makers Regarding the Protection of the Ozone Layer: 1988-1999, UNEP/Earthprint, Nairobi, Kenya, 1999.

Arblaster, J. and Meehl, G.: Contributions of external forcings to southern annular mode trends, J. Climate, 19, 2896-2905, 2006.

Baldwin, M., and Dameris, M.: Climate-ozone connections, Chapter 5, Scientific Assessment of Ozone Depletion: 2006, World Meteorological Organization Global Ozone Research and Monitoring Project, Report No. 50, Geneva, WHO, 5.1-5.49, 2007.

Belkin, I. M.: Rapid warming of large marine ecosystems, Prog. Oceanogr., 81, 207-213, 2009.

Burke, L.: Reefs at Risk Revisited, World Resources Institute, Washington DC, 2011.

Cantin, N., Cohen, A., Karnauskas, K., Tarrant, A., and McCorkle, D.: Ocean warming slows coral growth in the central red sea, Science, 329, 322-325, 2010.

Carlton, J. A. and Giese, A. B. S.: A Reanalysis of Ocean Climate Using Simple Ocean Data Assimilation (SODA), Mon. Weather Rev., 136, 2999-3017, 2008.

Castro, C. B. and Pires, D. O.: Brazilian coral reefs: what we already know and what is still missing, B. Mar. Sci., 69, 357-371, 2001.

Cataldo, M., Evangelista, H., Simões, J. C., Godoi, R. H. M., Simmonds, I., Hollanda, M. H., Wainer, I., Aquino, F., and Van Grieken, R.: Mineral dust variability in central West Antarctica associated with ozone depletion, Atmos. Chem. Phys., 13, 21652175, doi:10.5194/acp-13-2165-2013, 2013.

Cayan, D.: Latent and sensible heat flux anomalies over the northern oceans: driving the sea surface temperature, J. Phys. Oceanogr., 22, 859-881, 1992.

Chelton, D., Schlax, M., Samelson, R., and de Szoeke, R.: Global observations of large oceanic eddies, Geophys. Res. Lett., 34, L15606, doi:10.1029/2007GL030812, 2007.

Chen, D., Busalacchi, A., and Rothstein, L.: The roles of vertical mixing, solar radiation, and wind stress in a model simulation of the sea surface temperature seasonal cycle in the tropical Pacific Ocean, J. Geophys. Res, 99, 20345-20359, 1994.

Coles, S. and Jokiel, P.: Synergistic effects of temperature, salinity and light on the hermatypic coral montipora verrucosa, Mar. Biol., 49, 187-195, 1978.

Dalazoana, R., Luz, R. T., and Freitas, S. R. C.: Estudos do NMM a partir de séries temporais maregráficas e de altimetria por satélite visando a integração da rede vertical brasileira ao SIRGAS, Rev. Bras. Cartogr., 57, 140-153, 2005. da Silva, L., Júnior, G., and Amaral, F.: Estudo do branqueamento do coral (Siderastrea stellata verrill, 1868) da praia de Porto de Galinhas-PE, in: Jornada de Pesquisa, Ensino e Extensão, Annals of JEPEX, Recife, 2009.

Evangelista, H., Godiva, D., Sifeddine, A., Leão, Z.M.A.N., Rigozo, N.R., Segal, B., Ambrizzi, T., Kampel, M., Kikuchi, R., and Le Cornec, F.: Evidences linking ENSO and coral growth in the Southwestern-South Atlantic, Clim. Dynam., 29, 869-880, 2007.

Farman, J. C., Gardiner, B. G., and Shanklin, J. D.: Large losses of total ozone in Antarctica reveal seasonal $\mathrm{ClO}_{x}=\mathrm{NO}_{x}$ interaction, Nature, 315, 207-210, 1985.

Foltz, G., Grodsky, S., Carton, J., and McPhaden, M.: Seasonal mixed layer heat budget of the tropical Atlantic ocean, J. Geophys. Res, 108, 3146, doi:10.1029/2002JC001584, 2003.

Gillett, N. and Thompson, D.: Simulation of recent Southern Hemisphere climate change, Science, 302, 273-275, 2003.

Hartmann, D., Wallace, J., Limpasuvan, V., Thompson, D., and Holton, J.: Can ozone depletion and global warming interact to produce rapid climate change?, P. Natl. Acad. Sci. USA, 97, 1412-1417, 2000.

Hashizume, H., Takeuchi, K., Xie, S., and Liu, W.: Local and remote atmospheric response to tropical instability waves - a global view from space, J. Geophys. Res., 106, 173-185, 2001.

Howe, S. and Marshall, A.: Temperature effects on calcification rate and skeletal deposition in the temperate coral, Plesiastrea versipora (Lamarck), J. Exp. Mar. Biol. Ecol., 275, 63-81, 2002.

Kang, S. M., Polvani, L. M., Fyfe, J. C., and Sigmond, M.: Impact of polar ozone depletion on subtropical precipitation, Science, 332, 951-954, 2011.

Kleypas, J. A., Danabasoglu, G., and Lough, J. M.: Potential role of the ocean thermostat in determining regional differences in coral reef bleaching events, Geophys. Res. Lett., 35, L03613, doi:10.1029/2007GL032257, 2008.

Knutson, D. W., Buddemeier, R. W., and Smith, S. V.: Coral chronologies: seasonal growth bands in reef corals, Science, 177, 270-272, 1972.

Lindzen, R. and Nigam, S.: On the role of sea surface temperature gradients in forcing low-level winds and convergence in the tropics, J. Atmos. Sci., 44, 2418-2436, 1987.

Lins-de-Barros, M. and Pires, D. O.: Comparison of the reproductive status of the scleractinian coral Siderastrea stellata throughout a gradient of 20ffof latitude, Braz. J. Oceanogr., 55, 67-69, 2007.

Lough, J.: Shifting climate zones for australia's tropical marine ecosystems, Geophys. Res. Lett., 35, L14708, doi:10.1029/2008GL034634, 2008.

Lough, J. and Barnes, D.: Several centuries of variation in skeletal extension, density and calcificationin massive porites colonies from the Great Barrier Reef: a proxy for seawater temperatureand a background of variability against which to identify unnatural change, J. Exp. Mar. Biol. Ecol., 211, 29-67, 1997.

Lough, J., Barnes, D., and McAllister, F.: Luminescent lines in corals from the Great Barrier Reef provide spatial and temporal records of reefs affected by land runoff, Coral Reefs, 21, 333343, 2002.

Mantua, N. J., Zhang, Y., Wallace, J. M., and Francis, R. C.: A Pacific interdecadal climate oscillation with impacts on salmon production, B. Am. Meteorol. Soc., 78, 1069-1079, 1997. 
Marshall, G.: Trends in the southern annular mode from observations and reanalysis, J. Climate, 16, 4134-4143, 2003.

McPhaden, M. and Hayes, S.: On the variability of winds, sea surface temperature, and surface layer heat content in the western Equatorial Pacific, J. Geophys. Res., 96, 3331-3342, 1991.

Miller, A. J., Cayan, D. R., Barnett, T. P., Graham, N. E., and Oberhuber, J. M.: The 1976-77 climate shift of the Pacific Ocean, Oceanography, 7, 21-26, 1994.

NOAA: The NCEP/NCAR Reanalysis Project, Boulder, Colorado, 15 USA, available at: http://www.esrl.noaa.gov/psd/, last access: in Janary 2016.

Nobre, P. and Shukla, J.: Variations of sea surface temperature, wind stress, and rainfall over the tropical Atlantic and South America, J. Climate, 9, 2464-2479, 1996.

O'Neill, L., Chelton, D., and Esbensen, S.: The effects of sstinduced surface wind speed and direction gradients on midlatitude surface vorticity and divergence, J. Climate, 23, 255-281, 2010.

JISAO: PDO, Pacific Decadal Oscillation, available at: http://www. jisao.washington.edu, last access: in January 2016.

Perlwitz, J., Pawson, S., Fogt, R., Nielsen, J., and Neff, W.: Impact of stratospheric ozone hole recovery on antarctic climate, Geophys. Res. Lett., 35, L08714, doi:10.1029/2008GL033317, 2008.

Pezza, A. B. and Ambrizzi, T.: Variability of Southern Hemisphere cyclone and anticyclone behavior: further analysis, J. Climate, 16, 1075-1083, 2003.

Polvani, L., Waugh, D., Correa, G., and Son, S.: Stratospheric ozone depletion: the main driver of 20th century atmospheric circulation changes in the Southern Hemisphere, J. Climate, 24, 795812, 2011.

Purich, A. and Son, S.: Impact of Antarctic ozone depletion and recovery on Southern Hemisphere precipitation, evaporation and extreme changes, J. Climate, 25, 3145-3154, 2012.

Randel, W. J. and Wu, F.: Cooling of the Arctic and Antarctic Polar Stratospheres due to ozone depletion, J. Climate, 12, 1467-1479, 1999.

Rayner, N. A., Parker, D. E. , Horton, E. B. , Folland, C. K. , Alexander, L. V. , Rowell, D. P., Kent, E. C., and Kaplan, A.: Global analyses of sea surface temperature, sea ice, and night marine air temperature since the late nineteenth century, J. Geophys. Res., 108, D144407, doi:10.1029/2002JD002670, 2003.

Shen, C.-C., Li, K.-S., Sieh, K., Natawidjaja, D., Cheng, H., Wang, X., Edwards, R. L., Lam, D. D., Hsieh, Y.-T., Fan, T.-Y., Meltzner, A. J., Taylor, F. W., Quinn, T. M., Chiang, H.-W., and Kilbourne, K. H.: Variation of initial ${ }^{230} \mathrm{Th}={ }^{232} \mathrm{Th}$ and limits of high precision U-Th dating of shallow-water corals, Geochim. Cosmochim. Ac., 72, 4201-4223, 2008.

Shen, C.-C., Kano, A., Hori, M., Lin, K., Chiu, T.-C., and Burr, G. S.: East Asian monsoon evolution and reconciliation of climate records from Japan and Greenland during the last deglaciation, Quaternary Sci. Rev., 29, 3327-3335, 2010.

Solomon, S.: Stratospheric ozone depletion: a review of concepts and history, Rev. Geophys., 37, 275-316, 1999.
Son, S., Polvani, L. M., Waugh, D. W., Akiyoshi, H., Garcia, R., Kinnison, D., Pawson, S., Rozanov, E., Shepherd, T. G., and Shibata, K.: The impact of stratospheric ozone recovery on the Southern Hemisphere westerly jet, Science, 320, 1486-1489, 2008.

Son, S., Tandon, N., Polvani, L., and Waugh, D.: Ozone hole and Southern Hemisphere climate change, Geophys. Res. Lett., 36, L15705, doi:10.1029/2009GL038671, 2009.

Sexton, D.: The effect of stratospheric ozone depletion on the phase of the Antarctic oscillation, Geophys. Res. Lett., 28, 3697-3700, 2001.

Shindell, D. and Schmidt, G.: Southern Hemisphere climate response to ozone changes and greenhouse gas increases, Geophys. Res. Lett., 31, L18209, doi:10.1029/2004GL020724, 2004.

Thompson, D. and Solomon, S.: Interpretation of recent Southern Hemisphere climate change, Science, 296, 895-899, 2002.

Thompson, D., Wallace, J., and Hegerl, G.: Annular modes in the extratropical circulation, Part II: trends, J. Climate, 13, 10181036, 2000.

Thompson, D., Solomon, S., Kushner, P. J., England, M. H., Grise, K. M., and Karoly, D. J.: Signatures of the Antarctic ozone hole in Southern Hemisphere surface climate change, Nat. Geosci., 4, 741-749, 2011.

Turner, J., Comiso, J. C., Marshall, G. J., Lachlan-Cope, T. A., Bracegirdle, T., Maksym, T., Meredith, M. P., Wang, Z., and Orr, A.: Non-annular atmospheric circulation change induced by stratospheric ozone depletion and its role in the recent increase of Antarctic sea ice extent, Geophys. Res. Lett., 36, L08502, doi:10.1029/2009GL037524, 2009.

Uppala, S. M., KÅllberg, P. W., Simmons, A. J., Andrae, U., Da Costa Bechtold, V., Fiorino, M., Gibson, J. K., Haseler, J., Hernandez, A., Kelly, G. A., Li, X., Onogi, K., Saarinen, S., Sokka, N., Allan, R. P., Andersson, E., Arpe, K., Balmaseda, M. A., Beljaars, A. C. M., Van De Berg, L., Bidlot, J., Bormann, N., Caires, S., Chevallier, F., Dethof, A., Dragosavac, M., Fisher, M., Fuentes, M., Hagemann, M. S., Hólm, E., Hoskins, B. J., Isaksen, L., Janssen, P. A. E. M., Jenne, R., Mcnally, A. P., Mahfouf, J.-F., Morcrette, J.-J., Rayner, N. A., Saunders, R. W., Simon, P., Sterl, A., Trenberth, K. E., Untch, A., Vasiljevic, D., Viterbo, P., and Woollen, J.: The ERA-40 re-analysis, Q. J. Roy. Meteorol. Soc., 131, 2961-3012, 2005.

Verrill, A. E.: Notice of the corals and echinoderms collected by Prof. C. F. Hartt, at the Abrolhos Reefs, province of Bahia, Brazil, 1867, Trans. Conn. Acad. Arts Sc., 1, 351-371, 1868

Wang, W. and McPhaden, M.: The surface-layer heat balance in the equatorial Pacific Ocean, Part II: interannual variability, J. Phys. Oceanogr., 30, 2989-3008, 2000. 